\title{
The Evolution and Ecology of Land Ownership
}

Hannah J. Haynie ${ }^{1}$, Geoff Kushnick ${ }^{2}$, Patrick H. Kavanagh ${ }^{3}$, Carol R Ember ${ }^{4}$, Claire Bowern ${ }^{5}$, Bobbi S. Low ${ }^{6}$, Ty Tuff $^{7}$, Bruno Vilela ${ }^{8}$, Kathryn R. Kirby ${ }^{9,10}$, Carlos A. Botero ${ }^{11}$, and Michael C. Gavin ${ }^{3,9 *}$

${ }^{1}$ Department of Linguistics, University of Colorado, Boulder, CO, USA

${ }^{2}$ School of Archaeology and Anthropology, Australian National University, Canberra, ACT, Australia

${ }^{3}$ Department of Human Dimensions of Natural Resources, Colorado State University, Fort Collins, CO, USA

${ }^{4}$ Human Relations Area Files, Yale University, New Haven, CT, USA

${ }^{5}$ Department of Linguistics, Yale University, New Haven, CT, USA

${ }^{6}$ School for Environment and Sustainability, University of Michigan, Ann Arbor, MI, USA

${ }^{7}$ Department of Biology, McGill University, Montreal, QC, Canada

${ }^{8}$ Institute of Biology, Universidade Federal da Bahia, Salvador, BA, Brazil

${ }^{9}$ Department of Linguistic and Cultural Evolution, Max Planck Institute for The Science of Human History, Jena, Germany

${ }^{10}$ Department of Ecology and Evolutionary Biology, University of Toronto, Toronto, ON, Canada

${ }^{11}$ Department of Biology, Washington University in St. Louis, St. Louis, MO, USA

* Email: michael.gavin@colostate.edu

\section{Abstract}

Land ownership norms play a central role in social-ecological systems, and have been studied extensively as a component of ethnographies. Yet only recently has the distribution of land ownership norms across cultures been examined from evolutionary and ecological perspectives. Here we incorporate evolutionary and macroecological modelling to test associations between land ownership norms and environmental, subsistence, and cultural contact predictors for societies in the Bantu language family. We find that Bantu land ownership norms likely evolved on a unilinear trajectory, but not necessarily one requiring consistent increase in exclusivity as suggested by prior theory. Our macroecological analyses suggest that Bantu societies are more likely to have some form of ownership when their neighbors also do. We also find an effect of environmental productivity, supporting resource defensibility theory, which posits that land ownership is more likely where productivity is predictable. We find less support for a proposed link between agricultural intensification and land ownership. Overall, we demonstrate the value of combining analytical approaches from evolution and ecology to test diverse hypotheses on land ownership across a range of disciplines.

\section{Introduction}

Cultural norms that govern human relationships with land help shape social-ecological systems. Land tenure systems, particularly land ownership, influence natural resource management, resource distribution, and many traits that comprise cultural diversity. Land tenure has been studied extensively from cultural, political, economic, and natural resource management perspectives (e.g. 1-6), and theories on property rights date back centuries(7-9). The evolutionary and biogeographic dynamics that shape these systems over time and space, however, remain largely a matter of theory. Although land tenure includes several related rights and norms (e.g., usufruct and inheritance), land ownership is a central component and serves as the centerpiece of our analyses. Here we couple biogeographic and evolutionary analyses to investigate temporal and spatial patterns in land ownership norms in a sample of Bantu

44 societies. 
How do land ownership norms change over time? Are there fixed trajectories of change, or can any form of land ownership evolve into any other form? Early theories argued for rectilinear trajectories, in which societies progressed in one direction through a series of established stages of land tenure linked to subsistence approaches (e.g. 10,11). The rectilinear model began with a nomadic phase characterized by no land ownership, and continued through a pastoralist phase, in which groups owned land, followed by two agriculturalist phases. In the first, patrilineal kin groups held land; and in the second, individual farmers owned land. Many critiques have emerged regarding strict rectilinear models, including the possibility that societies may progress or regress along the spectrum of different forms of land ownership (no ownership (N), group ownership (G), kin ownership (K), and individual ownership (I)) depending on the cost and benefits of owning land in different forms (12-15). Although less explored, other trajectories may also be possible in which land ownership change is not restricted to shifts up and down the N-G-K-I continuum, but rather any form of ownership can change into any other form if conditions are suitable (see Fig 2a; (16)). Here we use phylogenetic methods adopted from evolutionary biology to distinguish between alternative evolutionary trajectories of land ownership.

Land ownership norms not only vary over time, but also across space (see Figure 1). Long-standing debates spanning multiple academic disciplines still exist regarding which factors shape spatial patterns in land ownership. Here we test three prominent hypotheses. First, cultural norms can be shaped by both vertical (i.e. from one generation to the next) and horizontal (i.e. among individuals within the same generation) cultural transmission. If vertical transmission is prominent, we would expect closely related societies to share similar land ownership norms. If horizontal transmission plays a major role, we would expect societies that are in closer contact (e.g., neighboring groups) to have similar ownership norms. Second, research on territoriality by ecologists, anthropologists, and economists have converged on the theory of resource defensibility (17-23). This theory argues that as the density and predictability of resources increases so to do the benefits of defending these resources, which leads to a greater probability of individuals or groups owning land $(6,15,24-26)$. Third, the use and defense of resources may be linked to subsistence strategies, and certain strategies may work better with specific land ownership norms. For example, communal land ownership may support the transhumance of pastoralist groups that is often associated with high environmental variability $(6,27-29)$. Others suggest that private property co-evolved with agriculture (30), and that increasing intensification of agriculture is also associated with land ownership $(6,12)$. We use a multi-model inference approach to explore the relative power of each of these three sets of factors to predict whether a society possess some form of land ownership (G, K or I) versus none $(\mathrm{N})$.

We focus our analysis on the temporal and spatial variation in land ownership on Bantu-speaking societies, which offers several advantages. A wide range of land tenure systems have historically been employed by Bantu-speaking populations, ranging from individual private ownership to systems in which land is not owned by common individuals or families (e.g. 31-34). The historical relationships among Bantu societies are well-characterized by a language phylogeny(35), making it possible to implement phylogenetic analysis of trait evolution (36). Furthermore, Bantu-speaking societies employ a range of subsistence strategies, from an absence of agriculture to highly intensified agricultural production, making it possible to test the theoretical association between crop cultivation and land ownership.

\section{Materials and methods}




\subsection{Data}

The data for this study include land ownership norms coded for 73 societies that are included in the reference phylogeny for Bantu (35), and for which Ethnographic Atlas data and environmental variables are available through the D-PLACE database (37-43) (See supplementary material for full dataset). This constitutes a maximal sample of Bantu-speaking societies for which both phylogenetic and cultural information are available. Variables describing the annual mean and variance for temperature and precipitation in D-PLACE are from the Baseline Historical (1900-1949) CCSM ecoClimate model (spatial resolution of $0.5^{\circ} ;(40)$ ). Monthly net primary productivity (NPP) reflect annual mean, variance and constancy from data obtained from the MODIS dataset (spatial resolution of $1 \mathrm{~km}$; (41)). Elevation and distance to coast in D-PLACE are from the Global Multi-resolution Terrain Elevation Data of the U.S. Geological Survey (44). Agricultural intensity represents the Ethnographic Atlas variable EA028 $(37,38)$. We recoded EA028 as a binary variable expressing the presence or absence of intensive agriculture.

We coded land tenure data based on ethnographic descriptions of each society (see supplementary materials). Following the coding procedures of Kushnick et al. (16), we coded each society's primary land ownership norm as no ownership (N), group ownership (G), kin ownership (K), or individual ownership (I). The land ownership variable used in this study thus encodes the land holding available to a majority of people in a particular society according to documented traditional or customary norms. We focus here on the earliest norms recorded in ethnographic literature to avoid, to the extent possible, known impacts of post-colonial political, economic, and social change (45). Where land tenure norms were described as undergoing transition, we coded those norms noted to be customary or to have pre-dated colonial influences. Our coding strategy departs from that described in Kushnick et al. (16) in that we do not consider ownership norms restricted to elite classes to be the main type of ownership in a society unless that norm is also available to ordinary members of the society. The land ownership variable presented here can thus be thought of as a majority land ownership norm.

To avoid problems of multicollinearity in environmental data we used principal component analysis (see supplementary materials, Fig S1). Based on eigenvalues, we used three components to capture the variability in environmental conditions across the region (Table S3). We refer to these components as environmental productivity, mountains, and productivity uncertainty. Following Vilela et al (46), the other composite variable included in this study characterizes each society's reliance on agriculture for subsistence, derived from a principal component analysis on Ethnographic Atlas variables that characterize dietary reliance on specific subsistence activities (see supplementary materials). 


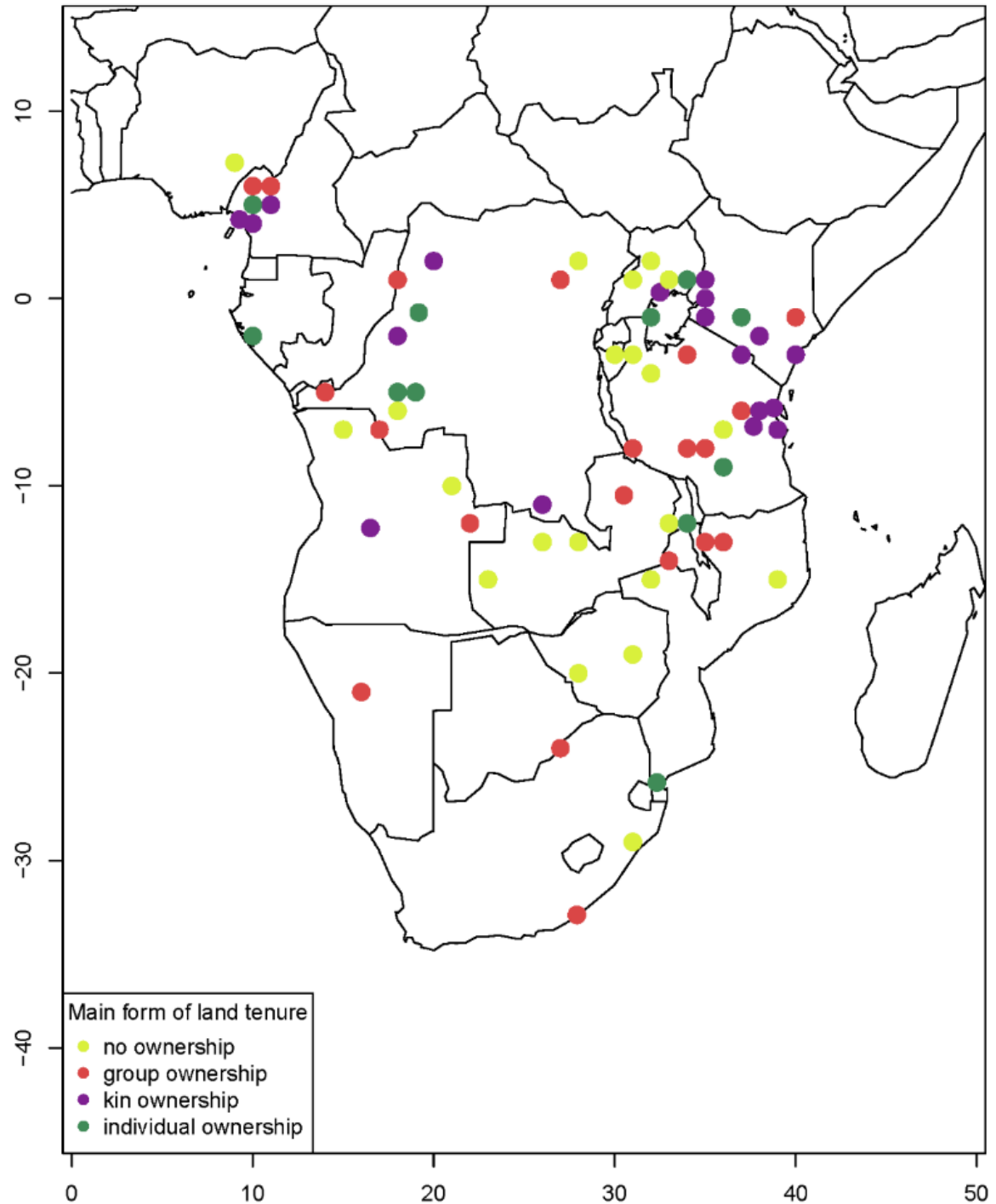

Figure 1: Land tenure norms associated with a majority of the population of societies in the sample (n=73).

\subsection{Phylogenetic analyses of evolution of land ownership}

We characterized the evolution of land ownership by measuring phylogenetic and geographic signal in the trait data, and modeling alternative evolutionary trajectories using maximum likelihood methods. These analyses paired land tenure data described above with Bantu language trees produced by Grollemund et al. (35). A 2,000 tree posterior sample from Bayesian Markov Chain Monte Carlo (MCMC) analysis on cognate data across 100 meanings in 424 Bantu and Bantoid languages (35) was pruned to retain only the 73 taxa for which land ownership data were available. We computed a maximum clade credibility (MCC) tree for this pruned tree sample using the TreeAnnotator package of BEAST v.2.4.7 (47). We used this MCC tree for the purposes of phylogenetic signal estimation. We performed model comparisons to test support for alternative evolutionary trajectories using the full 2,000 tree sample. 
We characterized the phylogenetic signal in land ownership using the D statistic for binary characters (48). This statistic uses the sum of sister-clade differences to characterize the distribution of observed trait states across taxa and measures the similarity of the observed trait distribution to the expected for different processes. $\mathrm{D}=0$ resembles a distribution as expected under a Brownian Motion, whereas $\mathrm{D}=1$ resembles expectations under random conditions, which may be due to fast evolutionary processes, for example. Negative values of D indicate more clumping than expected by Brownian motion model, and values above 1 indicate more dispersed trait values than expected just by chance. We estimated the D statistic and associated p-value for each land tenure norm on the MCC tree and the full tree sample using the caper package for R (49). Following Kushnick et al. (16) we also calculated the D statistic on a tree derived by hierarchical clustering on geographic distances to estimate the degree of geographic organization in each individual ownership norm's distribution.

We used the MultiState phylogenetic comparative method of the BayesTraits V3 software package to evaluate possible evolutionary trajectories for land ownership norms $(50,51)$. This method uses a continuous-time Markov model to infer the evolution of a categorical trait on the trees in a given tree sample. In this method transition rate parameters express the probabilities of changes from each state to any other state for the trait of interest. We use these parameters to model alternative trajectories for the evolution of ownership, setting certain parameters to zero values to reflect the impossibility of a particular transition under a given theoretical model. We used maximum likelihood analyses without a covarion to estimate model parameters. Likelihood scores for each model and each tree in the sample were used to calculate Akaike Information Criterion values (AIC $=2 \mathrm{k}-2 \operatorname{lnLh}$, where $\mathrm{k}$ is the number of unrestricted parameters).

We evaluated the same set of candidate models of land ownership trait evolution as Kushnick et al. (16). Each model expresses a possible trajectory for changing land ownership norms (Fig. 2a). This set of trajectories includes a full model, in which all 12 possible transitions from one state to another are allowed, as well as multiple variations on progressive and non-progressive models. For progressive models, both an Exclusivity Gain trajectory (N-G-K-I) and an Alternative trajectory (N-I-G-K) were explored. Progressive models are characterized as Rectilinear (sequential changes in a single direction), Unilinear (sequential changes in either direction), or Relaxed Unilinear (sequential changes in either direction, plus transitions from any state to $\mathrm{N}$ ). Among the non-progressive models, the No Loss model allows all transitions except changes to non-ownership from any other state. The Loss for Change model allows transitions in either direction between Non-Ownership and each other state, but no transitions between G, K, and I. The Gain from None model is further restricted to allow only transitions from nonownership to any other state, while disallowing changes in the other direction. The Unstable Group model allows transitions to group only from non-ownership but allows all possible transitions between other pairs of states. The Kin-Group model allows all possible transitions except for any transition away from kin. Finally, the Corporate model requires that once kin or individual ownership arises, only transitions between these two states are allowed. All other transitions are possible under this model.

\subsection{Multi-model inference of drivers of spatial patterns in land ownership}

The expansion of Bantu across the central and southern regions of Africa brought speakers of these languages into a range of environments from forests to savannas and put them in contact with other cultures, including hunter-gatherer and pastoralist populations. To test the relative influence of possible environmental, subsistence, and contact-related predictors on Bantu land ownership norms, we applied a multi-model inference approach based on logistic regression to model the presence of land ownership in 
Bantu societies $(15,52)$. For this analysis we recoded land ownership as a binary variable $(0=$ no ownership; 1 = group, kin, or individual ownership).

The full model in this analysis predicted land ownership as a function of intensive agriculture, reliance on agriculture, environmental productivity, productivity uncertainty, mountains, distance to coast, and a neighbor effect. The neighbor effect expresses the proportion of the eight closest spatial neighbor societies that shares a given society's primary land ownership norm, and it serves as a proxy for horizontal transmission of land ownership norms. We centered (by subtracting mean) and scaled (by standard deviation) all continuous variables included in the model using the scale function in $\mathrm{R}(53)$. We also included language classification information from Glottolog (Narrow Bantu subgroups Ababuan, Bantu-A-B10-B20-B30, Central Western Bantu, and East Bantu as well as the Southern Bantoid classifications Tivoid and Wide Grassfields) as a random effect to account for shared ancestry (54-56). Due to missing data for at least some of the variables of interest, we excluded 8 societies from the analysis of spatial variation, resulting in a sample size of 65 societies (see supplementary materials).

We used multimodel inference (52) to examine all possible alternative models involving subsets of the fixed and random effects in this full model (Table S6). This was carried out using the MuMIn package for $\mathrm{R}$ (57). We implemented model averaging based on AIC weights to account for uncertainty across multiple competing models.

Two societies in the sample were non-agriculturalists. The Mbuti are generally considered a huntergatherer group, and the Herero rely largely on pastoralism. In addition, three other societies (Lozi (which use substantial animal husbandry and hunting), Sangu (for which animal husbandry is the other primary activity), and the Ngala (which have a high reliance on fishing) rely on agriculture for less than $50 \%$ of their subsistence (based on the Ethnographic Atlas variable EA005; $(37,38)$ ). Two of our independent variables focus on reliance on agriculture and intensive agriculture, both of which may be as relevant for these societies. In turn, we also ran our multimodel inference analysis with a sample that excluded these 5 societies $(n=60)$.

\section{Results}

\subsection{Evolutionary trajectories of land ownership}

D statistic values for non-ownership $(D=0.73)$ and group ownership $(D=0.75)$ are significantly different from $0(\mathrm{p}<.05)$ on the MCC tree, as well as on the full tree (see supplementary materials), suggesting a lack of phylogenetic signal for these forms of land tenure. The D-statistic for individual land ownership $(\mathrm{D}=1.13)$ is also significantly different from $0(\mathrm{p}=0.009)$ on the MCC tree and full posterior sample (see supplementary materials), but a D statistic greater than 1 indicates overdispersion of this trait. Kin ownership has a relatively low, positive $\mathrm{D}$ statistic $(\mathrm{D}=0.20)$ that is significantly different from $1(\mathrm{p}=$ $0.005)$, indicating moderate phylogenetic signal for this trait. All land tenure types have positive D statistics that are significantly different from 0 on the geographic tree, suggesting that no significant geographic "clumping" exists for any specific land ownership norm (see supplementary materials).

Based on AIC evidence, the Alternative Unilinear model best fits the patterns we see in land ownership in Bantu-speaking societies (Fig. 2b). Like the best models reported for the evolution of land tenure in Austronesian societies (16), this model implements a N-I-G-K trajectory that departs from the constant increase in exclusivity proposed in prior literature to explain the evolution of land tenure. However, we also find some support for the Exclusivity Gain configuration of the Unilinear model ( $\triangle \mathrm{AIC}=0.497$ ), 
which does restrict the trajectory of change in this trait to the traditional N-G-K-I pathway. The Loss for

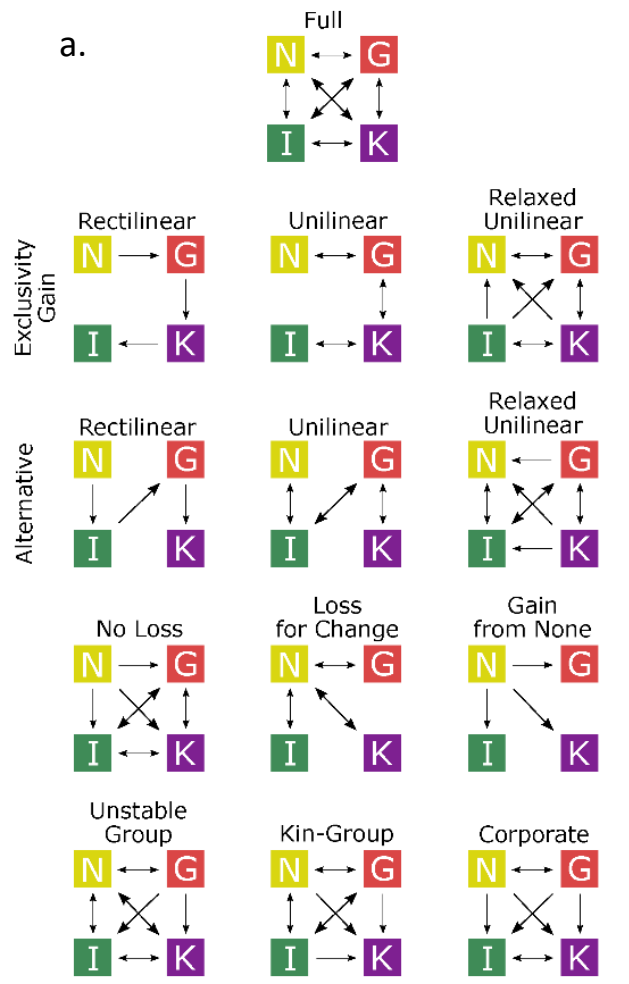

b.

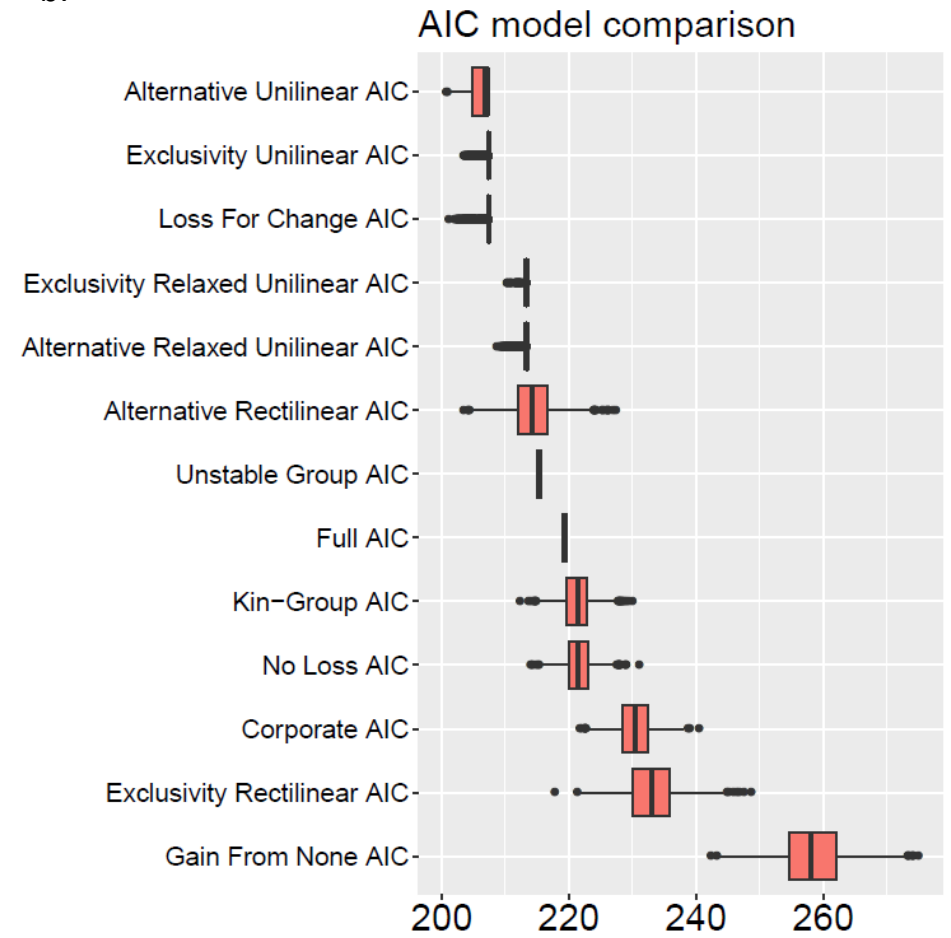

Figure 2: a) Models of land ownership change considered in phylogenetic analysis; b) AIC values for alternative models on 2,000 tree posterior sample.

\subsection{Drivers of spatial variation in land ownership}

To evaluate influences other than evolutionary tendencies on the land ownership norms of these societies, we used a multimodel averaging approach based on logistic regression, as described in Section 2.4. The $\mathrm{AICw}$ of the best model is 0.09 (see Table S5 in supplementary materials), suggesting that model averaging is an appropriate method for this study (52). Neighbor effect (proportion of neighboring societies with private ownership) is an important predictor of land ownership in this sample, occurring in all models with $\triangle \mathrm{AIC}<2$. The relatively large multimodel average effect size for this variable (Table 1) suggests that the land ownership practices of neighboring societies are important for predicting land ownership norms.

We also find evidence that land ownership might be more likely to occur where resource productivity is predictable; productivity uncertainty occurs in several models with $\Delta \mathrm{AIC}<2$ and is associated with a relatively small, negative coefficient in the averaged model. All other environmental variables contribute to a lesser extent to the averaged model, suggesting that they may play only a minor role in land ownership practices.

While we may have expected that agriculture, and in particular intensive agriculture, should be an important predictor of land ownership (12), we find that reliance on agriculture and intensive agriculture 
are associated with relatively small effect sizes and relatively low importance in the averaged model. While it is theoretically possible that redundancy in the characterization of subsistence may interfere with the identification of meaningful effects, no multicollinearity issues are identified in this dataset (VIF $<2$ for all variables; reliance on agriculture VIF $=1.53$, intensive agriculture VIF $=1.36$ ). This suggests that the relationship between the cultivation of crops and the protection of territory through land ownership is indeed less important than we would have expected. When we omitted the five societies that did not rely on agriculture for the majority of their subsistence ( $n=60$ societies, see Methods), results were qualitatively similar to those presented here for the full sample $(n=65)$ (see Tables S7 and S8).

We used $\mathrm{R}_{\text {GLMM }}^{2}$ to measure marginal and conditional fit of the averaged model reported in the main text. Marginal $\mathrm{R}_{\text {GLMM }}^{2}$ is 0.59 and conditional $\mathrm{R}_{\text {GLMM }}^{2}$ is 0.61 , suggesting that the language subgroup random effect does not account for a large proportion of the variation in land ownership. We found no evidence of spatial autocorrelation in model residuals (Moran's $\mathrm{I}=-0.006, \mathrm{p}=0.3$ ).

Table 1: Multi-model average for models of land ownership (full average). Intensive agriculture coded as binary (presence/absence of intensive agriculture; absence of intensive agriculture treated as reference level). Land ownership coded as binary (presencelabsence of any land ownership available to a majority of the society's population; absence of ownership for most community members treated as reference level). Standardized coefficients are presented. Marginal $R^{2}{ }_{G L M M}=0.59$, conditional $R^{2}{ }_{G L M M}=0.61$

\begin{tabular}{|l|l|l|l|l|}
\hline Parameter & $\boldsymbol{\beta}$ coefficient & Standard error & z value & RVI \\
\hline (Intercept) & -3.019 & 1.268 & 2.337 & 1.00 \\
\hline Neighbor Effect & 7.404 & 2.165 & 3.353 & 1.00 \\
\hline Productivity Uncertainty & -0.271 & 0.385 & 0.697 & 0.50 \\
\hline Reliance on Agriculture & 0.415 & 0.824 & 0.497 & 0.37 \\
\hline Intensive Agriculture & -0.353 & 0.754 & 0.463 & 0.35 \\
\hline Distance to Coast & -0.111 & 0.314 & 0.350 & 0.32 \\
\hline Mountains & -0.067 & 0.249 & 0.266 & 0.28 \\
\hline Productivity & 0.019 & 0.144 & 0.132 & 0.26 \\
\hline
\end{tabular}

\section{Discussion}

Our results provide new insights on the various pressures that impact land tenure over time and space. We find that unilinear trajectories and reversion to non-ownership in the process of change are potentially more consistent with Bantu land tenure patterns than alternative trajectories. We find evidence for a trajectory in which individual ownership may follow non-ownership on such a trajectory, contrary to expectations that ownership should evolve along a trajectory of increasing exclusivity of rights (cf. 10,11,13,16). Our results are similar to those for Austronesian societies reported in the only other phylogenetic-based analysis of land ownership to date (16). That we find evidence for this alternative pathway in a second major ethnolinguistic family suggests that the development of individual ownership norms directly from systems without any ownership may not be a tendency of a single set of related cultures but rather a more general pattern in the way land tenure systems develop over time.

We find support for multiple possible evolutionary pathways. This lack of resolution in the pathway analyses may, in part, be due to localized horizontal transfer. Our macroecological analyses find an influence of neighbors on land tenure strategies, and these localized horizontal transmission events may make it difficult to distinguish specific evolutionary pathways across the whole tree. 
One longstanding idea about other influences on land tenure focuses on the relationship between this trait and subsistence practices $(12,58-60)$. These theories propose that agricultural development and land ownership co-evolve, and might predict that societies with intensive agriculture would be particularly likely to recognize some form of land ownership. However, reliance on agriculture and intensive agriculture are not particularly important predictors of land ownership in our averaged model.

This result might be especially surprising from the perspective of traditional unilinear cultural evolution theories that tie agriculture and land tenure together on a progressive pathway toward cultural complexity. Among the 65 societies included in the relevant analysis, we find five that practice intensive agriculture but do not have land ownership. In most of these, including Lozi, Nyoro, and Soga, land is controlled by a king or chief and usufruct rights, but not ownership, are granted to individuals and families $(32,34,61)$. Although private citizens are allowed to live on and cultivate parcels of land, typical ownership rights such as the sale or rental of land are prohibited in these societies and in many cases land can be withdrawn from users and reassigned. It has been suggested that scarcity of arable land is a factor in the customary Bantu land tenure systems that allow ownership by common individuals or groups versus those that do not (31). This is consistent with more recent ideas about the evolutionary ecology of territoriality and real property, namely that scarcity of land is crucial to balancing resource-related benefits against the social and economic costs of long-term, exclusive control of land (62). With only two non-agricultural groups included in this sample (Mbuti and Herero), we are unable to draw comparisons about how land tenure norms in foraging or pastoralist societies compare to agriculturalist land ownership. However, our results suggest that agricultural cultivation does not predict the privatization of land ownership, but rather plays a modest role within a more complex suite of influences.

Early tests of resource defensibility theory, based largely on qualitative case studies or limited sample sizes, produced mixed results (17,21,63). More recently, Ember et al.(6) and Kavanagh et al.(15) found some support for resource defensibility theory in societies spread across the globe and using a range of different subsistence strategies. However, Freeman and Anderies (64) concluded that less predictable and less dense resources increased the probability of land ownership in hunter-gatherer societies. Here we find that uncertainty of productivity is negatively associated with land ownership. In other words, land ownership is more likely in locations where productivity is predictable. This echoes prior research which suggests that predictability of resources is a factor in determining whether resource defense is economically viable $(6,15,65)$. Private ownership of land may facilitate the defense of natural resources in environments where those resources are reliable enough to justify such actions.

The most important predictor of land ownership in our averaged model is the neighbor effect, which measures the proportion of neighboring societies that share similar ownership norms with a given society. Although none of the four norms of ownership (N, I, G, K) is individually clustered in space, as demonstrated by the measurement of geographic signal for each norm using the D statistic, our results indicate that societies may be more likely to have some form of ownership when nearby societies have any form of ownership. Indeed, the neighbor scores for societies that do have a majority norm of land ownership are significantly higher, on average, than the neighbor scores for societies without land ownership (mean $=0.73$ for societies with ownership; mean $=0.40$ for societies without ownership; $\mathrm{t}=$ $6.025, \mathrm{df}=37.205, \mathrm{p}<0.001$ ). Societies may adopt land ownership norms from nearby groups via direct observation or through horizontal cultural transmission mechanisms. However, we also cannot rule out the possibility that other mechanisms lead to similar norms among neighboring groups, including possible effects of other spatially-clustered environmental or social conditions (such as increased competition between groups within a given geographical location) that our data do not currently capture. 
Overall, we have used a combination of evolutionary and macroecological analyses to conclude that land ownership in Bantu-speaking societies is shaped by a complex set of forces that operate in cultural, environmental, and historical context.

\section{Data Accessibility}

All data are available from www.d-place.org and are listed in tables in the supplementary materials.

\section{Funding}

This research was funded by The National Science Foundation (award 1519987).

\section{Acknowledgements}

We thank the following people for research assistance with data coding: Richard Berl, Kaylin Clements, Anna Kellogg, Brock Mrofcza and Bergen Tjossem. We thank Russell Gray and Fiona Jordan for valuable discussions on the design of the study.

\section{References}

1. Feder G, Feeny D. Land Tenure and Property Rights: Theory and Implications for Development Policy. World Bank Econ Rev. 1991 Jan 1;5(1):135-53.

2. Platteau J-P. The Evolutionary Theory of Land Rights as Applied to Sub-Saharan Africa: A Critical Assessment. Development and Change. 1996;27(1):29-86.

3. Mackenzie AFD. Land Tenure and Biodiversity: An Exploration in the Political Ecology of Murang'a District, Kenya. Human Organization. 2003;62(3):255-66.

4. Peters PE. Challenges in Land Tenure and Land Reform in Africa: Anthropological Contributions. World Development. 2009 Aug 1;37(8):1317-25.

5. Robinson BE, Holland MB, Naughton-Treves L. Does secure land tenure save forests? A metaanalysis of the relationship between land tenure and tropical deforestation. Global Environmental Change. 2014 Nov 1;29:281-93.

6. Ember CR, Adem TA, Brougham T, Pitek E. Predictors of land privatization: Cross-cultural tests of defendability and resource stress theory. American Anthropologist. 2021;12(4):745-58.

7. Hobbes T. Leviathan, 1651. Scolar Press; 1651.

8. Locke J. Two treatises of government. Cambridge University Press; 1690.

9. Hume D. A treatise of human nature. Longmans; 1739.

10. de Laveleye E. De la propriété et de ses formes primitives. London: MacMillan; 1874.

11. Morgan LH. Ancient Society: Or, Researches in the Lines of Human Progress from Savagery, through Barbarism to Civilization. London: MacMillan; 1877.

12. Brown P, Podolefsky A. Population Density, Agricultural Intensity, Land Tenure, and Group Size in the New Guinea Highlands. Ethnology. 1976;15(3):211-38. 
13. Smith EA. Risk and uncertainty in the "original affluent society": Evolutionary ecology of resource sharing and land tenure. In: Ingold T, Riches D, Woodburn J, editors. Hunters and gatherers: History, evolution, and social change. Oxford: Berg; 1988. p. 222-52.

14. Netting RM. Smallholders, Householders: Farm Families and the Ecology of Intensive, Sustainable Agriculture. Stanford University Press; 1993.

15. Kavanagh PH, Haynie HJ, Kushnick G, Vilela B, Tuff T, Bowern C, et al. Drivers of global variation in land ownership. Ecography. 2020; 44(1):67-74.

16. Kushnick G, Gray RD, Jordan FM. The sequential evolution of land tenure norms. Evolution and Human Behavior. 2014 Jul 1;35(4):309-18.

17. Dyson-Hudson R, Smith EA. Human territoriality: an ecological reassessment. American Anthropologist. 1978;80(1):21-41.

18. Demsetz H. Toward a theory of property rights. The American economic review. 1967;347-59.

19. Lueck D. Common property as an egalitarian share contract. Journal of Economic Behavior \& Organization. 1994;25(1):93-108.

20. Anderson CL, Swimmer E. Some empirical evidence on property rights of first peoples. Journal of Economic Behavior \& Organization. 1997;33(1):1-22.

21. Baker MJ. An Equilibrium Conflict Model of Land Tenure in Hunter-Gatherer Societies. Journal of Political Economy. 2003;111(1):124-73.

22. Brown JL. The evolution of diversity in avian territorial systems. The Wilson Bulletin. 1964;160-9.

23. Maynard Smith J. Evolution and the Theory of Games. Cambridge University Press; 1982.

24. Rose CM. Several Futures of Property: Of Cyberspace and Folk Tales, Emission Trades and Ecosystems, The. Minn L Rev. 1998;83:129.

25. Chabot-Hanowell B, Smith EA. 5 Territorial and Nonterritorial Routes to Power: Reconciling Evolutionary Ecological, Social Agency, and Historicist Approaches. Archeological Papers of the American Anthropological Association. 2012 Mar 1;22(1):72-86.

26. Acheson JM, Begossi A, Berge E, Eggertsson T, Haller T, Hann C, et al. Private land and common oceans: analysis of the development of property regimes. Current Anthropology. 2015;56(1):28-55.

27. Ellis J, Galvin KA. Climate Patterns and Land-Use Practices in the Dry Zones of Africa. BioScience. 1994 May 1;44(5):340-9.

28. Charnley S. Pastoralism and Property Rights: The Evolution of Communal Property on the Usangu Plains, Tanzania. African Economic History. 1997 Jan 1;(25):97-119.

29. Nugent JB, Sanchez N. The local variability of rainfall and tribal institutions: the case of Sudan. Journal of economic behavior \& organization. 1999;39(3):263-91.

30. Bowles S, Choi J-K. Coevolution of farming and private property during the early Holocene. Proceedings of the National Academy of Sciences. 2013;110(22):8830-5. 
31. Dobson EB. Comparative Land Tenure of Ten Tanganyika Tribes. J Afr Admin. 1954;6(2):80-91.

32. Mugerwa PJN. Land Tenure in East Africa - Some Contrasts. Int'l \& Comp LQ Supp Pub. 1966;12:101-14.

33. Shipton P. Lineage and Locality as Antithetical Principles in East African Systems of Land Tenure. Ethnology. 1984;23(2):117-32.

34. Kajoba GM. Land use and land tenure in Africa: Towards an evolutionary conceptual framework. Dakar: Council for the Development of Social Science Research in Africa; 2002.

35. Grollemund R, Branford S, Bostoen K, Meade A, Venditti C, Pagel M. Bantu expansion shows that habitat alters the route and pace of human dispersals. Proceedings of the National Academy of Sciences. 2015;112(43):13296-301.

36. Mace R, Pagel M, Bowen JR, Gupta BKD, Otterbein KF, Ridley M, et al. The Comparative Method in Anthropology [and Comments and Reply]. Current Anthropology. 1994;35(5):549-64.

37. Kirby KR, Gray RD, Greenhill SJ, Jordan FM, Gomes-Ng S, Bibiko H-J, et al. D-PLACE: A Global Database of Cultural, Linguistic, and Environmental Diversity. PLoS One. 2016;11:e0158391.

38. Murdock GP. Ethnographic atlas: a summary. Ethnology. 1967;6(2):109-236.

39. Gray JP. A corrected ethnographic atlas. World Cultures. 1999;10(1):24-136.

40. Lima-Ribeiro MS, Varela S, González-Hernández J, Oliveira G de, Diniz-Filho JAF, Terribile LC. EcoClimate: A Database of Climate Data from Multiple Models for Past, Present, and Future for Macroecologists and Biogeographers. Biodiversity Informatics. 2015;10:1-21.

41. Running SW, Ramakrishna N, Glassy JM, Thornton PE. MODIS daily photosynthesis (PSN) and annual net primary production (NPP) product (MOD17) Algorithm Theoretical Basis Document [Internet]. 1999. Available from: http://www.ntsg.umt.edu/modis/ATBD/ATBD_MOD17_v21.pdf

42. Colwell RK. Predictability, constancy, and contingency of periodic phenomena. Ecology. 1974;1:1148-53.

43. Danielson JJ, Gesch DB. Global multi-resolution terrain elevation data 2010 (GMTED2010) [Internet]. 2011. Available from: http://pubs.usgs.gov/of/2011/1073/pdf/of2011-1073.pdf

44. U.S. Geological Survey. USGS EROS Archive - Digital Elevation - Global Multi-resolution Terrain Elevation Data 2010 (GMTED2010). 2010.

45. Cotula L, editor. Changes in Customary Land Tenure Systems in Africa. London: International Institute for Environment and Development; 2007.

46. Vilela B, Fristoe T, Tuff T, Kavanagh PH, Haynie HJ, Gray RD, et al. Cultural transmission and ecological opportunity jointly shaped global patterns of reliance on agriculture. Evolutionary Human Sciences. 2020;2:e563. DOI: https://doi.org/10.1017/ehs.2020.55

47. Bouckaert R, Heled J, Kühnert D, Vaughan T, Wu C-H, Xie D, et al. BEAST 2: A Software Platform for Bayesian Evolutionary Analysis. PLOS Computational Biology. 2014 Apr 10;10(4):e1003537. 
48. Fritz SA, Purvis A. Selectivity in Mammalian Extinction Risk and Threat Types: A New Measure of Phylogenetic Signal Strength in Binary Traits. Conservation Biology. 2010;24(4):1042-51.

49. Orme D, Freckleton R, Thomas G, Petzoldt T, Fritz S, Isaac N, et al. caper: Comparative Analyses of Phylogenetics and Evolution in R [Internet]. 2018. Available from: https://CRAN.Rproject.org/package $=$ caper

50. Pagel M. The Maximum Likelihood Approach to Reconstructing Ancestral Character States of Discrete Characters on Phylogenies. Cunningham C, editor. Systematic Biology. 1999 Jul $1 ; 48(3): 612-22$.

51. Pagel M, Meade A, Barker D. Bayesian Estimation of Ancestral Character States on Phylogenies. Thorne J, editor. Systematic Biology. 2004 Oct 1;53(5):673-84.

52. Burnham KP, Anderson DR. Model Selection and Multimodel Inference: A Practical InformationTheoretic Approach. 2nd ed. New York: Springer-Verlag; 2002.

53. R Core Team. R: A language and environment for statistical computing. Vienna, Austria: R Foundation for Statistical Computing; 2016.

54. Hammarström H, Forkel R, Haspelmath M, editors. Glottolog 4.0 [Internet]. Jena: Max Planck Institute for the Science of Human History; 2019. Available from: https://glottolog.org/

55. Gavin MC, Kavanagh PH, Haynie HJ, Bowern C, Ember CR, Gray RD, et al. The global geography of human subsistence. Royal Society Open Science. 2018;5: 171897. DOI: http://doi.org/10.1098/rsos.171897.

56. Botero CA, Gardner B, Kirby KR, Bulbulia J, Gavin MC, Gray RD. The ecology of religious beliefs. Proceedings of the National Academy of Sciences. 2014;111:16784-9.

57. Bartoń K. MuMIn: Multi-Model Inference [Internet]. 2020. Available from: https://CRAN.Rproject.org/package $=$ MuMIn

58. Boserup E. The conditions of agricultural growth: the economics of agrarian change under population pressure. London: George Allen \& Unwin; 1965.

59. Bowles S, Choi J-K. Coevolution of Farming and Private Property During the Early Holocene. Proceedings of the National Academy of Sciences of the United States of America. 2013;110:8830 5.

60. Otsuka K, Place F. Land tenure and agricultural intensification in Sub-Saharan Africa. In: Monga C, Lin JY, editors. The Oxford Handbook of Africa and Economics Volume 2: Policies and Practices. Oxford: Oxford University Press; 2015. p. 289-306.

61. Fallers AL. The Politics of Landholding in Busoga. Economic Development and Cultural Change. 1955;3(3):260-70.

62. Smith EA, Borgerhoff Mulder M, Bowles S, Gurven M, Hertz T, Shenk MK. Production Systems, Inheritance, and Inequality in Premodern Societies: Conclusions. Current Anthropology. 2010;51:85-94. 
470

471

472

473

474

475

476

477

478

479

480

481

482
63. Cashdan E, Barnard A, Bicchieri MC, Bishop CA, Blundell V, Ehrenreich J, et al. Territoriality among human foragers: ecological models and an application to four Bushman groups [and Comments and Reply]. Current Anthropology. 1983;47-66.

64. Freeman J, Anderies JM. A comparative ethnoarchaeological analysis of corporate territorial ownership. Journal of archaeological science. 2015;54:135-47.

65. Dyson-Hudson R, Smith EA. Human Territoriality: An Ecological Reassessment. American Anthropologist. 1978;80:21-41. 


\section{Supplementary Materials}

\section{Land tenure coding}

Land tenure was coded for a sample of societies that represents the maximal overlap between the Grollemund et al. (2014) Bantu language phylogeny, the Bantu societies included in the Ethnographic Atlas, and the societies for which published ethnographies were accessible. This sample reflects a compromise between completeness of data, sample size, and coding effort.

Land tenure has been coded in many ways in prior research (e.g. 10,13,14,16). We adopt the system described in Kushnick et al.(16) for two reasons: 1) this system focuses on land ownership norms, and 2) this system of representing each society with the norm that applies to a majority of its population is compatible with the analytical techniques we used. We adapted this system for our uses by not including forms of land ownership restricted to elites (kings, political leaders) as primary forms of land tenure.

The variable created through this coding process encodes the primary land ownership norm for each society as a categorical variable. We define the primary land ownership norm as the norm associated with the majority of people in a society at the time of ethnographic description. Where multiple norms apply to an entire population we considered the extent and use of lands associated with each norm to determine which was the primary norm. For example, a society with kin ownership of farming lands but collective (group) ownership of ceremonial sites would be coded as K (kin).

This schema categorized societies into four categories of land ownership. Non-ownership describes societies in which the majority of people own no land. Usufruct rights may be granted to individuals, kin groups, or other groups in non-ownership societies, but crucially land is not owned or is held in trust for the community by a ruler or leader. Group ownership describes societies in which land is owned by groups of related and unrelated individuals, such as villages. In kin ownership societies a majority of people own land as part of kin groups, such as lineages or bilateral kin groups. Individual ownership indicates that the majority of individuals in a society are able to hold land. We collected additional information on elite ownership (land holding by rulers or members of privileged classes) and on the existence of multiple norms in a society. However, our coding of data for these analyses assigned exactly one primary norm $(\mathrm{N}, \mathrm{G}, \mathrm{K}$, or I) to each society in the sample.

All land tenure coding was completed by two coders. Duplicate coding of 17 societies in the sample was used to confirm an acceptable level of inter-coder reliability; the remainder of the dataset was coded by a single coder. Inter-coder reliability for the independent categorization of the main land ownership norm in the 17 societies coded by both coders was $76 \%$. Cases involving coder disagreement were revisited by the team to reconcile differences, resulting in full resolution of all coding differences in this sample through discussion (100\% agreement). Subsequent to this inter-coder reliability test and training, all difficult coding decisions were discussed by at least two members of the research team to ensure a high level of consistency in the data.

See Kushnick et al. (2014) for further discussion of the practicalities of land tenure coding and the representation of primary land ownership norm as a single multistate trait in phylogenetic comparative methods. 
Table S1: Primary land ownership norms and identifying information for Bantu societies in sample.

$523 n=73$.

\begin{tabular}{|c|c|c|c|c|c|}
\hline $\begin{array}{l}\text { D-PLACE } \\
\text { Society } \\
\text { Name }\end{array}$ & $\begin{array}{l}\text { Bantu Language Taxon } \\
\text { Name }\end{array}$ & $\begin{array}{l}\text { EA } \\
\text { ID }\end{array}$ & $\begin{array}{l}\text { Primary } \\
\text { Land } \\
\text { Ownership }\end{array}$ & Source & Date Range \\
\hline Mbuti & D211_Kango & Aa5 & $\mathrm{N}$ & Putnam 1963 & ca. $1940-1960$ \\
\hline Lozi & K21_Lozi & $\mathrm{Ab03}$ & $\mathrm{N}$ & Prins 1980 & 1876-1896 \\
\hline Tsonga & S53_Tsonga & $\mathrm{Ab} 04$ & I & Junod 1927 & 1895-1927 \\
\hline Herero & R31_Herero & $\mathrm{Ab} 1$ & $\mathrm{G}$ & Vedder, H. 1928 & Pre-1925 \\
\hline Xhosa & S41_Xhosa & Ab11 & $\mathrm{G}$ & Soga 1932 & ca. $1930-1939$ \\
\hline Zulu & S42-Zulu & $\mathrm{Ab} 12$ & $\mathrm{~N}$ & Cetewayo et al. 1978 & $1800-1884$ \\
\hline Tswana & S31_Tswana & $\mathrm{Ab} 13$ & $\mathrm{G}$ & Schapera 1953 & ca. 1950 \\
\hline Shona & S11_Shona & Ab18 & $\mathrm{N}$ & Bullock 1950 & 1901-1949 \\
\hline Mbundu & R11_Umbundu & $\mathrm{Ab} 5$ & $\mathrm{~K}$ & McCulloch 1952 & ca. 1950 \\
\hline Ndebele & S44_Ndebele & Ab9 & $\mathrm{N}$ & Kuper 1955 & 1872 \\
\hline Chewa & N31_Chewa & Ac10 & $\mathrm{G}$ & Hodgson 1933 & ca. 1933 \\
\hline Luvale & K14_Lwena & Ac11 & $\mathrm{G}$ & White 1955 & ca. 1950 \\
\hline Chokwe & K11_Ciokwe & Ac12 & $\mathrm{N}$ & McCulloch 1951 & Pre-1951 \\
\hline Tonga & M64_Tonga & Ac13 & I & Van Velsen 1964 & 1930-1952 \\
\hline Bakongo & H16a_Kisikongo_2013 & Ac14 & $\mathrm{N}$ & $\begin{array}{l}\text { Weeks } 1913 \\
\text { Torday and Joyce }\end{array}$ & $1900-1915$ \\
\hline Mbala & H41_Mbala & Ac15 & I & 1905 & ca. 1900 \\
\hline Suku & $\begin{array}{l}\text { H32_Suku } \\
\text { H131_Kisundi_Congo_Kimo }\end{array}$ & Ac17 & $\mathrm{N}$ & Kopytoff 1965 & ca. $1950-1960$ \\
\hline Sundi & ngo_1988 & Ac18 & $\mathrm{G}$ & Laman 1953 & 1891-1919 \\
\hline Yaka & H31_Yaka & Ac20 & $\mathrm{G}$ & Torday 1906 & 1906 \\
\hline Bunda & B84_Mbunda & Ac21 & I & Torday 1905 & ca. 1900 \\
\hline Songo & B85 $\bar{d}$ _Nsongo & Ac25 & $\mathrm{K}$ & Richards 1950 & ca. 1950 \\
\hline Bemba & M42_Bemba & Ac3 & $\mathrm{G}$ & Richards 1939 & ca. 1939 \\
\hline Kaonde & L41_Kaonde & Ac32 & $\mathrm{N}$ & Watson 1954 & Pre-1952 \\
\hline Kunda & N42_Kunda & Ac37 & $\mathrm{N}$ & Bruwer et al 1958 & Pre-1955 \\
\hline Nyasa & N11_Manda & Ac39 & $\mathrm{G}$ & Johnson 1922 & Pre-1920 \\
\hline Makua & P31_Emakhua & Ac42 & $\mathrm{N}$ & Tew 1950 & ca. 1950 \\
\hline Lamba & M5s̄_Lamba & Ac5 & $\mathrm{N}$ & Doke 1931 & ca. 1930 \\
\hline Ndembu & L52_Lunda & Ac6 & $\mathrm{K}$ & Turner 1957 & ca. 1957 \\
\hline Yao & P21_Yao & Ac7 & $\mathrm{G}$ & Mitchell 1952 & 1946-1949 \\
\hline Ngoni & N12_Ngoni & Ac9 & $\mathrm{N}$ & Barnes 1954 & ca. 1950 \\
\hline Nyoro & JE11_Runyoro & Ad02 & $\mathrm{N}$ & Beattie 1971 & Pre-1950 \\
\hline Kikuyu & E51_Kikuyu & Ad04 & I & Kenyatta 1953 & 1920-1938 \\
\hline Gisu & JE31_Lumasaaba & Ad09 & I & La Fontaine 1959 & 1890-1954 \\
\hline Bena & G63_Bena & Ad11 & I & Culwick et al. 1935 & 1928-1933 \\
\hline Gusii & JE42̄ Gusii & Ad12 & $\mathrm{K}$ & Mayer 1949 & 1946-1948 \\
\hline Luguru & G35_L_Luguru & Ad14 & $\mathrm{K}$ & Beidelman 1967 & ca. 1960 \\
\hline Fipa & M13_Fipa & Ad19 & $\mathrm{G}$ & Willis 1966 & ca. 1966 \\
\hline Sukuma & F21_Sukuma & $\operatorname{Ad} 22$ & $\mathrm{G}$ & Malcolm 1953 & ca. $1950-1959$ \\
\hline Sangu & G61_Sangu & $\operatorname{Ad} 23$ & $\mathrm{G}$ & Mumford 1934 & Pre-1930 \\
\hline Gogo & G11_Gogo & $\operatorname{Ad} 24$ & $\mathrm{~N}$ & Rigby 1966 & ca. $1960-1969$ \\
\hline Kwere & G32_Kwere & Ad27 & $\mathrm{K}$ & Beidelman 1967 & ca. 1960 \\
\hline Zigula & G31_Zigua & $\operatorname{Ad} 28$ & $\mathrm{~K}$ & Biedelman 1967 & 1894 \\
\hline Chagga & E62 $\overline{2} \mathrm{~A}$ _Kimochi & Ad3 & $\mathrm{K}$ & Stahl 1964 & 1960 \\
\hline Giriama & E72a_Giryama & Ad32 & $\mathrm{K}$ & Barrett 1911 & ca. 1911 \\
\hline Pokomo & E71A_Upper_Pokomo & Ad33 & G & $\begin{array}{l}\text { Prins } 1952 \\
\text { Middleton and }\end{array}$ & ca. 1950 \\
\hline Kamba & E55_Kamba & $\operatorname{Ad} 34$ & $\mathrm{~K}$ & Kershaw 2017 & 1920-1947 \\
\hline Meru & E53_Meru & Ad35 & $\mathrm{K}$ & Middleton 1965 & Pre-1929 \\
\hline
\end{tabular}




$\begin{array}{ll}\text { Vugusu } & \text { JE31c_Bukusu } \\ \text { Haya } & \text { JE22_Haya } \\ \text { Soga } & \text { JE16_Lusoga } \\ \text { Sumbwa } & \text { F23_Sumbwa } \\ \text { Toro } & \text { JE12_Rutooro } \\ \text { Zinza } & \text { JE23_Zinza } \\ \text { Kaguru } & \text { G12_Kagulu } \\ \text { Ngulu } & \text { G34_Nguungulu } \\ \text { Ganda } & \text { JE15_Luganda } \\ \text { Hehe } & \text { G62_Hehe } \\ & \\ \text { Nkundo } & \text { C61_Mongo } \\ & \\ \text { Rundi } & \text { JD62_Rundi } \\ \text { Duala } & \text { A24_Duala } \\ \text { Kpe } & \text { A22_Bakweri } \\ \text { Ekonda } & \text { C61E_Konda } \\ \text { Ngala } & \text { C36d_Lingala } \\ \text { Ndaka } & \text { D21_Baali } \\ \text { Ngombe } & \text { C41_Ngombe } \\ \text { Mpongwe } & \text { B11a_Mpongwe } \\ \text { Bafia } & \text { A53_Bafia_rikpa } \\ \text { Bali Nyonga } & \text { Mungaka_Grassfields } \\ \text { Bamileke } & \text { Fefe_Grassfields } \\ \text { Bamun } & \text { Bamun_Grassfields } \\ \text { Kom } & \text { Kom_Grassfields } \\ \text { Widikum } & \text { Moghamo_Grassfields } \\ \text { Tiv } & \text { Tiv_Tivoid } \\ \end{array}$

$\begin{array}{llll}\text { Ad41 } & \text { K } & \begin{array}{l}\text { Wagner 1949 } \\ \text { Cory and Hartnoll }\end{array} & \text { Pre-1940 } \\ & & 1971 & \text { ca. } 1970 \\ \text { Ad42 } & \text { I } & \begin{array}{l}\text { Roscoe 1911 } \\ \text { Forde and Abrahams }\end{array} & \text { ca. 1911 } \\ \text { Ad46 } & \text { N } & 1967 & \text { Pre-1967 } \\ & & \text { Forde 1962 } & \text { Pre-1950 } \\ \text { Ad47 } & \text { N } & \text { Forde and Taylor 1962 } & \text { Pre-1962 } \\ \text { Ad48 } & \text { N } & \text { Beidelman 1967 } & 1967 \\ \text { Ad49 } & \text { N } & \text { Beidelman 1967 } & \text { ca. 1960 } \\ \text { Ad50 } & \text { G } & \text { Roscoe 1902 } & \text { ca. 1900 } \\ \text { Ad51 } & \text { K } & \text { Brown and Hutt 1935 } & \text { ca. 1935 } \\ \text { Ad7 } & \text { K } & \text { Hulstaert \& Vizedom } & \\ \text { Ad8 } & \text { G } & \text { 1938 } & 1930-1938 \\ & & \text { Meyer \& Handzik } & \\ \text { Ae04 } & \text { I } & \text { 1916 } & 1812-1911 \\ & & \text { Ardener 1956 } & \text { ca. 1955 } \\ \text { Ae08 } & \text { N } & \text { Ardener 1957 } & \text { ca. 1950 } \\ \text { Ae12 } & \text { K } & \text { Brown 1944 } & \text { ca. 1944 } \\ \text { Ae2 } & \text { K } & \text { Weeks 1913 } & 1890 \\ \text { Ae20 } & \text { K } & \text { Schebesta 1933 } & 1929-1930 \\ \text { Ae28 } & \text { G } & \text { Wolfe 1961 } & \text { ca. 1960 } \\ \text { Ae33 } & \text { G } & \text { Burton 1968 } & \text { ca. 1968 } \\ \text { Ae39 } & \text { K } & \text { Dugast et al 1954 } & \text { ca. 1950 } \\ \text { Ae46 } & \text { I } & \text { Covarrubias 1937 } & \text { Pre-1937 } \\ \text { Ae48 } & \text { K } & \text { Littlewood 1954 } & \text { ca. 1950 } \\ \text { Ae49 } & \text { G } & \text { ca. 1910-1950 } \\ \text { Ae5 } & \text { I } & \text { Littlewood 1954 } & \text { ca. 1950 } \\ \text { Ae50 } & \text { G } & \text { Jefferys 1951 } & \text { ca. 1950 } \\ \text { Ae54 } & \text { G } & \text { Kaberry 1952 } & 1907-1953 \\ \text { Ae59 } & \text { K } & \text { Bohannan 1968 } & \\ \text { Ah03 } & \text { N } & & \\ & & & \end{array}$

Societies excluded from multimodel inference due to missing data

527 The following societies were removed from the sample prior to biogeographic analysis as a result of

528 missing data:

529 Tonga (Ac13)

530 Mbala (Ac15)

531 Nyasa (Ac39)

532 Makua (Ac42)

533 Haya (Ad42)

534 Bali Nyonga (Ae49)

535 Kom (Ae54)

536 Widikum (Ae59) 
Manuscript Preprint. Currently in revision following peer-review

541 Table S2. Data on cultural and environmental variables for all Bantu included in the evolutionary and multimodel inference analyses

542

\begin{tabular}{|c|c|c|c|c|c|c|c|c|c|c|c|c|c|c|c|c|}
\hline ID & $\begin{array}{c}\text { DPLACE } \\
\text { Name }\end{array}$ & $\begin{array}{c}\text { Glottolog } \\
\text { Subgroup }\end{array}$ & $\begin{array}{c}\text { Main } \\
\text { Land } \\
\text { Tenure } \\
\text { Norm } \\
\end{array}$ & $\begin{array}{c}\text { Reliance } \\
\text { on } \\
\text { Agric. }\end{array}$ & $\begin{array}{c}\text { Intensive } \\
\text { Agric. }\end{array}$ & Lat. & Long. & Elev. & Slope & $\begin{array}{c}\text { Annual } \\
\text { Mean } \\
\text { Precip. }\end{array}$ & $\begin{array}{l}\text { Annual } \\
\text { Precip. } \\
\text { Variance }\end{array}$ & $\begin{array}{c}\text { Annual } \\
\text { Mean } \\
\text { Temp. }\end{array}$ & $\begin{array}{c}\text { Annual } \\
\text { Temp. } \\
\text { Variance }\end{array}$ & $\begin{array}{c}\text { Monthly } \\
\text { Mean } \\
\text { NPP }\end{array}$ & $\begin{array}{c}\text { NPP } \\
\text { Variance }\end{array}$ & $\begin{array}{c}\text { Distance } \\
\text { to coast }\end{array}$ \\
\hline Aa5 & Mbuti & Ababuan & $\mathrm{N}$ & -1.58 & 0 & 2 & 28 & 805 & 0.60 & 243308 & 9483286472 & 21.42 & 0.31 & 3.49 & 1.60 & 1448.49 \\
\hline Ab1 & Herero & $\begin{array}{l}\text { Central- } \\
\text { Western- } \\
\text { Bantu }\end{array}$ & G & -0.24 & 0 & -21 & 16 & 1442 & 0.90 & 52226 & 4874838526 & 21.99 & 7.87 & 0.43 & 0.18 & 217.22 \\
\hline Ab11 & Xhosa & East-Bantu & G & 0.55 & 0 & -32.9 & 27.9 & 445 & 1.82 & 96542 & 3179657454 & 17.10 & 8.93 & 2.86 & 1.22 & 10.78 \\
\hline $\mathrm{Ab} 12$ & Zulu & East-Bantu & $\mathrm{N}$ & 0.90 & 0 & -29 & 31 & 281 & 2.43 & 165894 & 11178307664 & 16.45 & 8.37 & 2.74 & 0.82 & 52.92 \\
\hline Ab13 & Tswana & East-Bantu & G & 0.85 & 0 & -24 & 27 & 976 & 0.78 & 78321 & 5544617497 & 18.42 & 14.38 & 0.89 & 0.32 & 596.05 \\
\hline Ab18 & Shona & East-Bantu & $\mathrm{N}$ & 0.29 & 0 & -19 & 31 & 1310 & 0.99 & 80001 & 9844635651 & 18.62 & 12.61 & 1.83 & 0.56 & 388.32 \\
\hline Ab3 & Lozi & East-Bantu & $\mathrm{N}$ & 0.09 & 1 & -15 & 23 & 1048 & 0.20 & 116188 & 18444498077 & 21.27 & 9.70 & 1.18 & 0.87 & 1055.19 \\
\hline $\mathrm{Ab} 4$ & Tsonga & East-Bantu & I & 0.63 & 0 & -24 & 32 & 168 & 0.49 & 102638 & 10551815964 & 20.20 & 9.70 & 1.37 & 0.33 & 189.43 \\
\hline Ab5 & Mbundu & $\begin{array}{l}\text { Central- } \\
\text { Western- } \\
\text { Bantu }\end{array}$ & K & 0.29 & 0 & -12 & 16 & 1655 & 1.21 & 122623 & 13467979126 & 17.79 & 2.70 & 2.36 & 0.92 & 241.11 \\
\hline Ab9 & Ndebele & East-Bantu & $\mathrm{N}$ & 0.87 & 0 & -20 & 28 & 1290 & 0.79 & 81721 & 10979414178 & 19.92 & 13.82 & 1.46 & 0.78 & 695.71 \\
\hline Ac10 & Chewa & East-Bantu & $\mathrm{G}$ & -0.06 & 0 & -14 & 33 & 1037 & 1.84 & 106647 & 15053921231 & 19.14 & 11.42 & 2.14 & 1.19 & 595.32 \\
\hline Ac11 & Luvale & $\begin{array}{l}\text { Central- } \\
\text { Western- } \\
\text { Bantu }\end{array}$ & G & -0.10 & 0 & -12 & 22 & 1080 & 0.07 & 140787 & 19771051651 & 20.23 & 5.38 & 0.85 & 0.43 & 893.23 \\
\hline Ac12 & Chokwe & $\begin{array}{l}\text { Central- } \\
\text { Western- } \\
\text { Bantu }\end{array}$ & $\mathrm{N}$ & 0.09 & 0 & -10 & 21 & 1090 & 0.64 & 130821 & 13961412818 & 20.50 & 2.80 & 1.79 & 1.37 & 789.17 \\
\hline Ac14 & Bakongo & $\begin{array}{l}\text { Central- } \\
\text { Western- } \\
\text { Bantu }\end{array}$ & $\mathrm{N}$ & 0.15 & 0 & -7 & 15 & 1001 & 1.25 & 104336 & 7683087818 & 22.15 & 0.97 & 2.57 & 0.66 & 224.08 \\
\hline
\end{tabular}


Manuscript Preprint. Currently in revision following peer-review

\begin{tabular}{|c|c|c|c|c|c|c|c|c|c|c|c|c|c|c|c|c|}
\hline Ac17 & Suku & $\begin{array}{l}\text { Central- } \\
\text { Western- } \\
\text { Bantu }\end{array}$ & $\mathrm{N}$ & -0.20 & 0 & -6 & 18 & 875 & 1.28 & 138863 & 9110469846 & 21.48 & 0.74 & 1.63 & 1.01 & 572.91 \\
\hline Ac18 & Sundi & $\begin{array}{l}\text { Central- } \\
\text { Western- } \\
\text { Bantu }\end{array}$ & G & 0.14 & 0 & -5 & 14 & 401 & 1.55 & 134134 & 8573238351 & 23.37 & 0.72 & 2.00 & 0.75 & 184.70 \\
\hline Ac20 & Yaka & $\begin{array}{l}\text { Central- } \\
\text { Western- } \\
\text { Bantu }\end{array}$ & G & 0.39 & 0 & -7 & 17 & 639 & 1.39 & 111927 & 7184397498 & 21.53 & 0.94 & 1.85 & 1.10 & 426.57 \\
\hline Ac21 & Bunda & $\begin{array}{l}\text { Central- } \\
\text { Western- } \\
\text { Bantu }\end{array}$ & I & 0.42 & 0 & -5 & 19 & 643 & 1.53 & 158148 & 10819803484 & 22.74 & 0.56 & 1.30 & 0.94 & 709.88 \\
\hline Ac25 & Songo & $\begin{array}{l}\text { Central- } \\
\text { Western- } \\
\text { Bantu }\end{array}$ & $\mathrm{K}$ & -0.05 & 0 & -5 & 18 & 599 & 1.90 & 151544 & 9502551210 & 22.34 & 0.57 & 1.66 & 1.20 & 600.72 \\
\hline Ac3 & Bemba & East-Bantu & G & -0.08 & 0 & -11 & 31 & 1332 & 0.75 & 121032 & 19280474471 & 17.73 & 9.60 & 2.50 & 1.16 & 944.41 \\
\hline Ac32 & Kaonde & $\begin{array}{l}\text { Central- } \\
\text { Western- } \\
\text { Bantu }\end{array}$ & $\mathrm{N}$ & -0.25 & 0 & -13 & 26 & 1269 & 0.65 & 130320 & 21038146658 & 18.57 & 10.60 & 2.18 & 1.96 & 1179.43 \\
\hline Ac37 & Kunda & East-Bantu & $\mathrm{N}$ & -0.19 & 0 & -15 & 32 & 656 & 1.81 & 94551 & 14090898866 & 22.44 & 11.09 & 1.63 & 1.07 & 585.57 \\
\hline Ac5 & Lamba & East-Bantu & $\mathrm{N}$ & -0.17 & 0 & -13 & 28 & 1222 & 0.61 & 123074 & 20070415029 & 17.72 & 11.93 & 2.05 & 1.59 & 1021.30 \\
\hline Ac6 & Ndembu & $\begin{array}{l}\text { Central- } \\
\text { Western- } \\
\text { Bantu }\end{array}$ & $\mathrm{K}$ & 0.24 & 0 & -11 & 26 & 1497 & 0.84 & 146960 & 23765211571 & 18.28 & 7.46 & 2.15 & 1.66 & 1326.30 \\
\hline Ac7 & Yao & East-Bantu & $\mathrm{G}$ & 0.25 & 0 & -13 & 36 & 711 & 1.09 & 108717 & 14422661246 & 19.98 & 7.86 & 2.27 & 1.00 & 476.87 \\
\hline Ac9 & Ngoni & East-Bantu & $\mathrm{N}$ & 0.27 & 0 & -12 & 33 & 1182 & 0.89 & 108968 & 16053942987 & 19.36 & 10.26 & 1.94 & 0.69 & 764.28 \\
\hline Ad11 & Bena & East-Bantu & I & 0.82 & 1 & -9 & 36 & 585 & 1.95 & 118309 & 12754658363 & 18.97 & 6.44 & 2.45 & 0.76 & 365.88 \\
\hline $\operatorname{Ad} 12$ & Gusii & East-Bantu & $\mathrm{K}$ & 1.05 & 0 & -1 & 35 & 1772 & 1.28 & 71490 & 6601926733 & 19.02 & 1.64 & 2.59 & 0.34 & 605.34 \\
\hline Ad14 & Luguru & East-Bantu & $\mathrm{K}$ & 0.40 & 0 & -8 & 38 & 230 & 0.82 & 110656 & 7589578679 & 23.71 & 2.94 & 1.46 & 0.38 & 135.21 \\
\hline Ad19 & Fipa & East-Bantu & G & 0.33 & 0 & -8 & 31 & 1466 & 2.17 & 123075 & 18758274140 & 18.85 & 5.12 & 2.19 & 0.90 & 884.63 \\
\hline $\operatorname{Ad} 2$ & Nyoro & East-Bantu & $\mathrm{N}$ & 0.62 & 1 & 2 & 32 & 1057 & 0.40 & 144039 & 15069126112 & 22.58 & 1.30 & 1.92 & 0.70 & 1050.80 \\
\hline
\end{tabular}


Manuscript Preprint. Currently in revision following peer-review

\begin{tabular}{|c|c|c|c|c|c|c|c|c|c|c|c|c|c|c|c|c|}
\hline $\operatorname{Ad} 22$ & Sukuma & East-Bantu & G & 1.05 & 1 & -3 & 34 & 1342 & 0.50 & 100790 & 14915127800 & 20.38 & 1.69 & 1.38 & 0.55 & 605.38 \\
\hline $\operatorname{Ad} 23$ & Sangu & East-Bantu & $\mathrm{G}$ & 0.88 & 1 & -8 & 34 & 1186 & 1.04 & 103942 & 13978275716 & 18.35 & 6.06 & 1.81 & 0.72 & 564.02 \\
\hline $\operatorname{Ad} 24$ & Gogo & East-Bantu & $\mathrm{N}$ & 0.89 & 0 & -7 & 36 & 1082 & 4.73 & 105667 & 10965837982 & 19.46 & 4.98 & 2.08 & 0.46 & 321.80 \\
\hline $\operatorname{Ad} 27$ & Kwere & East-Bantu & $\mathrm{K}$ & 0.41 & 0 & -7 & 39 & 84 & 0.46 & 111773 & 4935576660 & 24.30 & 2.85 & 2.00 & 0.21 & 34.94 \\
\hline $\operatorname{Ad} 28$ & Zigula & East-Bantu & $\mathrm{K}$ & 0.58 & 0 & -5.8 & 38.8 & 146 & 0.59 & 111335 & 4389031613 & 22.36 & 2.85 & 1.85 & 0.16 & 3.51 \\
\hline $\mathrm{Ad} 3$ & Chagga & East-Bantu & $\mathrm{K}$ & 0.86 & 1 & -3 & 37 & 1403 & 3.02 & 69842 & 3910439083 & 19.05 & 2.86 & 2.23 & 0.14 & 306.80 \\
\hline $\operatorname{Ad} 32$ & Giriama & East-Bantu & $\mathrm{K}$ & 0.73 & 0 & -3 & 40 & 20 & 0.20 & 77809 & 3537188378 & 25.39 & 1.74 & 1.56 & 0.23 & 18.48 \\
\hline $\operatorname{Ad} 33$ & Pokomo & East-Bantu & $\mathrm{G}$ & -0.03 & 1 & -1 & 40 & 88 & 0.09 & 58571 & 2579307447 & 26.09 & 2.78 & 0.69 & 0.11 & 134.52 \\
\hline $\operatorname{Ad} 34$ & Kamba & East-Bantu & $\mathrm{K}$ & 0.97 & 1 & -2 & 38 & 680 & 0.99 & 70370 & 2466144649 & 19.36 & 2.88 & 1.32 & 0.23 & 256.42 \\
\hline $\operatorname{Ad} 35$ & Meru & East-Bantu & $\mathrm{K}$ & 0.79 & 0 & 0 & 35 & 1848 & 2.15 & 68198 & 6129817057 & 19.40 & 1.24 & 4.39 & 0.24 & 651.60 \\
\hline $\mathrm{Ad} 4$ & Kikuyu & East-Bantu & I & 1.04 & 1 & -1 & 37 & 1444 & 1.33 & 52670 & 2351512834 & 17.92 & 2.07 & 1.80 & 0.33 & 403.12 \\
\hline $\operatorname{Ad} 41$ & Vugusu & East-Bantu & $\mathrm{K}$ & 1.10 & 0 & 1 & 35 & 1868 & 2.27 & 72322 & 6707058434 & 20.57 & 1.64 & 2.61 & 0.54 & 709.76 \\
\hline Ad46 & Soga & East-Bantu & $\mathrm{N}$ & 0.61 & 1 & 1 & 33 & 1106 & 0.64 & 128027 & 14799781041 & 22.47 & 1.45 & 3.04 & 0.45 & 900.13 \\
\hline Ad47 & Sumbwa & East-Bantu & $\mathrm{N}$ & 0.63 & 1 & -4 & 32 & 1167 & 0.75 & 126958 & 20139363151 & 21.23 & 1.65 & 1.72 & 0.75 & 783.54 \\
\hline $\operatorname{Ad} 48$ & Toro & East-Bantu & $\mathrm{N}$ & 0.90 & 0 & 1 & 31 & 1256 & 1.14 & 164579 & 14829464236 & 20.79 & 0.56 & 4.11 & 0.73 & 1102.29 \\
\hline $\operatorname{Ad} 49$ & Zinza & East-Bantu & $\mathrm{N}$ & 0.89 & 0 & -3 & 31 & 1245 & 1.22 & 143991 & 18849962472 & 17.49 & 1.61 & 2.19 & 0.63 & 921.30 \\
\hline Ad50 & Kaguru & East-Bantu & G & 0.61 & 0 & -6 & 37 & 886 & 3.10 & 99676 & 5888824305 & 20.30 & 4.78 & 2.35 & 0.33 & 196.30 \\
\hline Ad51 & Ngulu & East-Bantu & $\mathrm{K}$ & 0.43 & 0 & -6 & 38 & 290 & 0.87 & 118774 & 4557872667 & 21.11 & 3.79 & 1.86 & 0.37 & 85.62 \\
\hline $\mathrm{Ad} 7$ & Ganda & East-Bantu & $\mathrm{K}$ & 0.50 & 1 & 1 & 32 & 1139 & 0.83 & 143340 & 15581893329 & 22.49 & 0.99 & 4.08 & 0.61 & 1000.31 \\
\hline $\mathrm{Ad} 8$ & Hehe & East-Bantu & $\mathrm{G}$ & 0.84 & 1 & -8 & 35 & 1664 & 2.11 & 106154 & 13269084146 & 18.05 & 5.92 & 2.72 & 0.37 & 460.53 \\
\hline Ad9 & Gisu & East-Bantu & I & 0.61 & 0 & 1 & 34 & 1325 & 1.43 & 96256 & 10801510855 & 21.77 & 1.62 & 2.60 & 0.25 & 802.88 \\
\hline Ae12 & Duala & $\begin{array}{l}\text { Bantu-A- } \\
\text { B10-B20- } \\
\text { B30 }\end{array}$ & $\mathrm{K}$ & 0.41 & 0 & 4 & 10 & 148 & 1.05 & 205861 & 10244752778 & 24.24 & 0.33 & 1.81 & 0.63 & 22.80 \\
\hline Ae2 & Kpe & $\begin{array}{l}\text { Bantu-A- } \\
\text { B10-B20- } \\
\text { B30 }\end{array}$ & $\mathrm{K}$ & 0.60 & 0 & 4.2 & 9.3 & 261 & 2.30 & 212616 & 14404955165 & 24.95 & 0.34 & 1.71 & 0.56 & 24.27 \\
\hline $\mathrm{Ae} 20$ & Ekonda & $\begin{array}{l}\text { Central- } \\
\text { Western- } \\
\text { Bantu }\end{array}$ & $\mathrm{K}$ & 0.18 & 0 & -2 & 18 & 313 & 0.29 & 193130 & 9767982930 & 23.17 & 0.35 & 2.41 & 1.22 & 739.25 \\
\hline
\end{tabular}


Manuscript Preprint. Currently in revision following peer-review

\begin{tabular}{|c|c|c|c|c|c|c|c|c|c|c|c|c|c|c|c|c|}
\hline Ae28 & Ngala & $\begin{array}{l}\text { Central- } \\
\text { Western- } \\
\text { Bantu }\end{array}$ & G & 0.06 & 0 & 1 & 18 & 325 & 0.15 & 188284 & 6321638490 & 22.94 & 0.27 & 2.67 & 1.08 & 896.57 \\
\hline Ae33 & Ndaka & Ababuan & G & 0.43 & 0 & 1 & 27 & 643 & 0.53 & 241762 & 6930236829 & 22.12 & 0.30 & 3.15 & 1.13 & 1495.40 \\
\hline Ae39 & Ngombe & $\begin{array}{l}\text { Central- } \\
\text { Western- } \\
\text { Bantu }\end{array}$ & $\mathrm{K}$ & -0.12 & 0 & 2 & 20 & 371 & 0.38 & 188204 & 7378565987 & 22.83 & 0.32 & 2.42 & 1.32 & 1121.19 \\
\hline Ae4 & Nkundo & $\begin{array}{l}\text { Central- } \\
\text { Western- } \\
\text { Bantu }\end{array}$ & I & -0.16 & 0 & 0 & 20 & 350 & 0.22 & 195206 & 6645956491 & 22.83 & 0.27 & 2.60 & 1.43 & 1042.80 \\
\hline Ae46 & Mpongwe & $\begin{array}{l}\text { Bantu-A- } \\
\text { B10-B20- } \\
\text { B30 }\end{array}$ & I & 0.22 & 0 & -2 & 10 & 147 & 1.14 & 176543 & 11513687094 & 25.51 & 0.62 & 2.20 & 1.09 & 54.40 \\
\hline Ae48 & Bafia & $\begin{array}{l}\text { Bantu-A- } \\
\text { B10-B20- } \\
\text { B30 }\end{array}$ & $\mathrm{K}$ & 0.62 & 0 & 5 & 11 & 602 & 1.13 & 197487 & 12733258455 & 21.62 & 0.88 & 2.49 & 0.48 & 172.88 \\
\hline Ae 5 & Bamileke & Grassfields & I & 0.63 & 0 & 5 & 10 & 550 & 2.98 & 202550 & 13678760552 & 22.49 & 0.77 & 2.85 & 1.27 & 102.55 \\
\hline Ae50 & Bamun & Grassfields & G & 0.45 & 0 & 6 & 11 & 834 & 1.57 & 187741 & 15731303961 & 20.75 & 1.36 & 2.94 & 0.63 & 252.80 \\
\hline Ae8 & Rundi & East-Bantu & $\mathrm{N}$ & 0.85 & 1 & -3 & 30 & 1565 & 2.67 & 156814 & 20029282678 & 16.58 & 1.58 & 2.28 & 0.37 & 1028.06 \\
\hline Ah3 & Tiv & Tivoid & $\mathrm{N}$ & -0.05 & 0 & 7 & 9 & 280 & 2.62 & 161827 & 13611477259 & 23.19 & 1.99 & 1.31 & 0.22 & 243.40 \\
\hline
\end{tabular}

544

545

546 


\section{Environmental PCA}

Data from 0.5 degree cells was extracted for all environmental variables from the region of Africa south of $9^{\circ} \mathrm{N}$ and east of $5^{\circ} \mathrm{E}$. We used data on the mean and variance values for temperature, precipitation, and NPP, as well as elevation, for each 0.5 degree cell in a latitude/longitude-delimited region of Africa that includes the locations of all attested Bantu languages to derive independent composite variables representing environmental conditions in the region of Africa where Bantu ethnolinguistic groups are found (Fig S1). All Bantu societies are found in this region, and the early $20^{\text {th }}$ century ecology of this region of Sub-Saharan Africa reflects the full spectrum of environmental conditions associated with the Bantu cultures in our sample. We use this data to derive independent environmental variables to represent these conditions using principal component analysis and to extract relevant values for sampled societies.

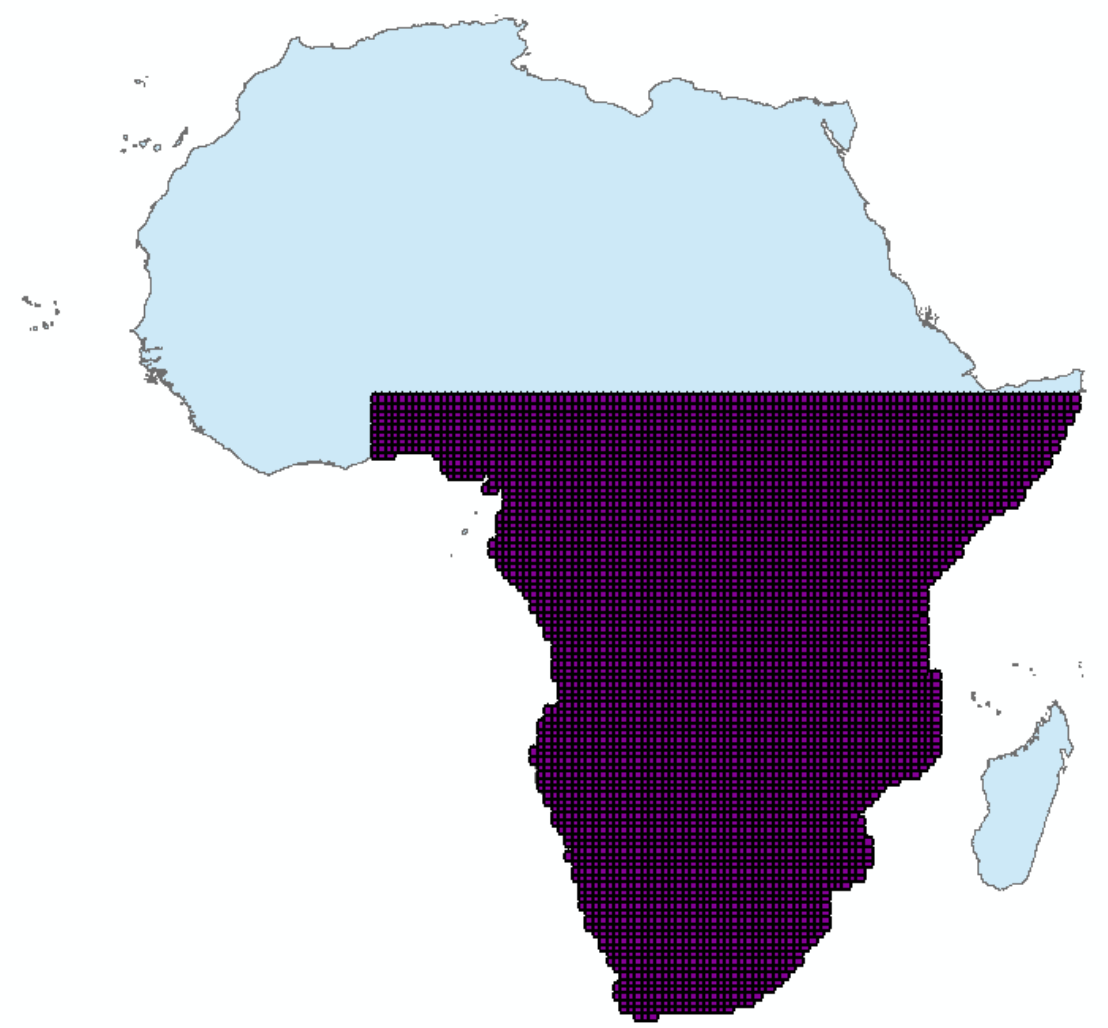

Figure S1: Environmental variables from 0.5 degree cells in the shaded region, including all of continental Africa south and east of $9^{\circ} \mathrm{N}, 5^{\circ} \mathrm{E}$, were used in principal component analysis. $n=5,005$.

Based on eigenvalues, the first three components were selected as the best representation of variability in this data. Component loadings and cumulative variance are reported in Table S3. The first of these components is positively associated with mean NPP and mean precipitation, and negatively associated with temperature variance. The second component is negatively associated with mean temperature and positively associated with elevation. The third component is positively associated with precipitation variance and NPP variance. 
Table S3: PCA on environmental variables from 0.5 degree cells across Sub-Saharan Africa. $n=5,005$.

\begin{tabular}{lrrrr}
\hline & PC1 & \multicolumn{1}{c}{ PC2 } & \multicolumn{1}{l}{ PC3 } & Uniqueness \\
\hline sqrt Mean NPP & $\mathbf{0 . 8 5}$ & 0.20 & 0.26 & 0.18 \\
Mean Precipitation & $\mathbf{0 . 8 1}$ & -0.11 & 0.44 & 0.13 \\
log Temperature Variance & $\mathbf{- 0 . 8 1}$ & 0.46 & 0.03 & 0.13 \\
Mean Temperature & -0.02 & $\mathbf{- 0 . 9 4}$ & -0.01 & 0.11 \\
Elevation & -0.09 & $\mathbf{0 . 8 7}$ & 0.15 & 0.22 \\
Precipitation Variance & 0.17 & 0.13 & $\mathbf{0 . 9 4}$ & 0.07 \\
sqrt NPP Variance & 0.60 & 0.06 & $\mathbf{0 . 6 8}$ & 0.17 \\
\hline SS Loadings & 2.43 & 1.92 & 1.63 & \\
Cumulative Variance & 0.35 & 0.62 & 0.85 & \\
\hline
\end{tabular}

\section{Reliance on agriculture}

572 Because reliance on multiple different subsistence strategies creates dependencies in subsistence data and because Ethnographic Atlas subsistence data is binned in ways that prevent simple arithmetic combinations, we describe reliance on agriculture as a single, continuous metric derived from scalar information about reliance on plant agriculture, animal husbandry, fishing, hunting, and gathering.

Following Vilela et al (46), this variable is derived from the Ethnographic Atlas variables EA001 Subsistence economy: gathering, EA002 Subsistence economy: hunting, EA003 Subsistence economy: fishing, EA004 Subsistence economy: animal husbandry, and EA005 Subsistence economy: agriculture. Murdock (38) coded each of these variables as a range of percentages of dietary composition (0-5\%, 6$15 \%, 16-25 \%, 26-35 \%, 36-45 \%, 56-65 \%, 66-75 \%, 76-85 \%, 86-100 \%)$. In order to account for the uncertainty created in the actual use of different subsistence strategies in this coding scheme, we generated 1000 possible combinations of exact percentage values while ensuring that these percentage values (i.e. the sum of dietary percentages across all subsistence sources) added to $100 \%$. We summarized these values into unique variables using principal component analysis for compositional data in the compositions package for $\mathrm{R}$. The first component in this analysis corresponds to increasing reliance on domesticated resources. We extracted scores for this first component for all societies in the sample as the variable 'reliance on agriculture'. See Vilela et al (46) for additional details on the construction of this 588 variable.

\section{D statistic of phylogenetic signal on full tree sample}

We calculated the D statistic to measure phylogenetic signal in each land tenure norm on all 2,000 trees in the posterior sample. Distributions of D across the entire tree sample, as well as distributions of p-values for comparisons with 0 (consistent with the Brownian motion model of evolution) and 1 (consistent with random distribution of trait values) are provided in Figure S2. 


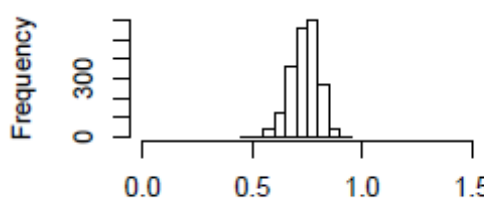

phyloD_results\$DEst_none

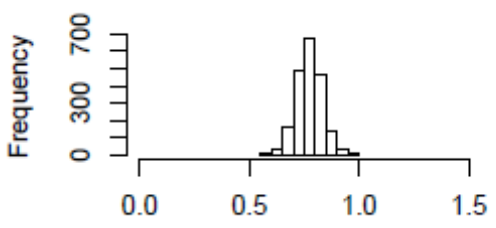

phyloD_results\$DEst_gr

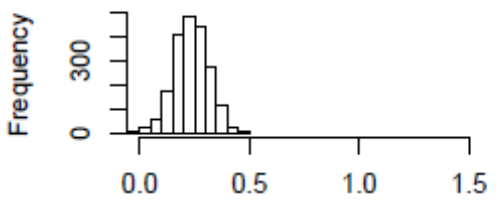

phyloD_results\$DEst_kin

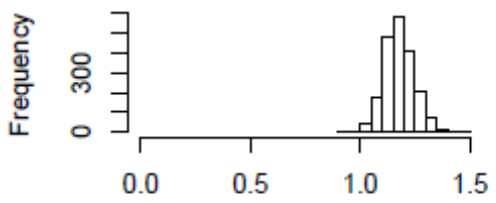

phyloD_results\$DEst_ind

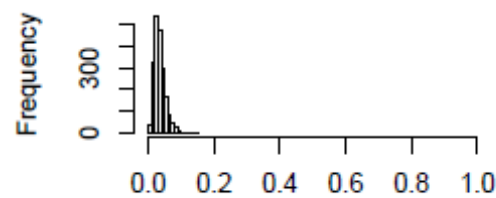

phyloD_results\$Pval0_none

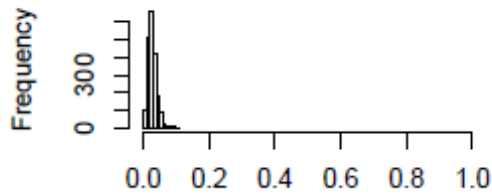

phyloD_results\$Pval0_gr

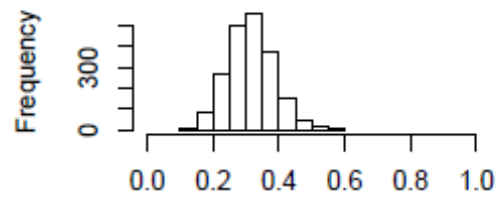

phyloD_results\$Pval0_kin

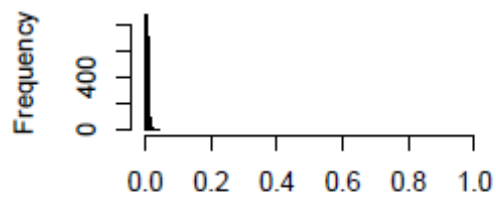

phyloD_results $\$ P$ val0_ind

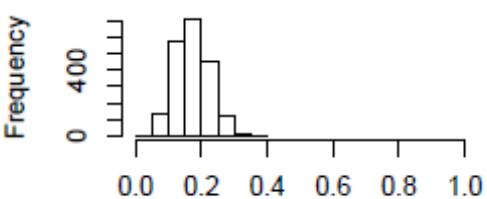

phyloD_results\$Pval1_none

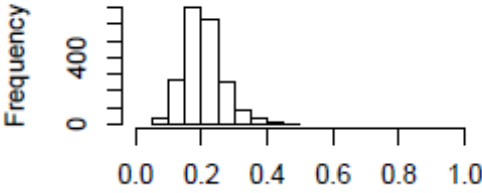

phyloD_results\$Pval1_gr

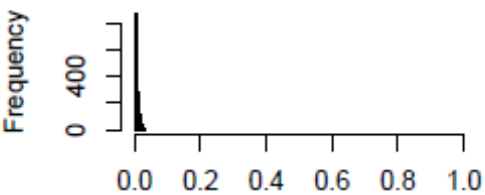

phyloD_results\$Pval1_kin

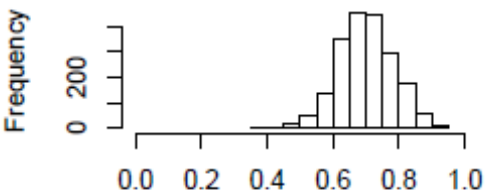

phyloD_results\$Pval1_ind

Figure S2: Phylogenetic signal measured by D-statistic on posterior tree sample (2,000 trees). X axis represents D-statistic. Y axis represents frequency.

\section{D statistic of phylogenetic signal on geographic tree}

600

A tree representing the geographic relationships between individual societies was constructed by applying

601 unweighted pair group method with arithmetic mean (UPGMA) hierarchical clustering to the spatial distances between societies. The $\mathrm{D}$ statistic of phylogenetic signal was measured on this tree for each land tenure norm to measure the spatial clustering of each individual form of land ownership. The results of 604 this analysis are reported in Table S3. 
Manuscript Preprint. Currently in revision following peer-review

605

606 Table S4: Phylogenetic signal measured by D-statistic on geographic tree (from hierarchical clustering 607 on lat/long coordinate distances)

\begin{tabular}{llll} 
LT Type & D-Statistic & p val 0 & p val 1 \\
\hline Non & 0.774 & 0.001 & 0.071 \\
Group & 0.842 & $<0.001$ & 0.144 \\
Kin & 0.799 & $<0.001$ & 0.094 \\
Individual & 1.125 & $<0.001$ & 0.745 \\
\hline
\end{tabular}

608

609

610 AIC comparison of evolutionary models

611 Additional information on the distribution of AIC values for alternative models of land tenure change are 612 reported in Table X. $\triangle \mathrm{AIC}$ is calculated based on the median AIC value for a particular model across the 613 entire tree sample $(\mathrm{n}=2,000)$.

614 Table S5: AIC comparison for alternative models of land ownership evolution

\begin{tabular}{l|rrrr} 
& \multicolumn{1}{|l}{$\begin{array}{l}\text { Median } \\
\text { AIC }\end{array}$} & \multicolumn{1}{l}{ Minimum } & \multicolumn{2}{l}{ Maximum } \\
& 206.815 & 200.677 & 207.312 & 0.000 \\
\hline Alternative Unilinear & 207.312 & 201.102 & 207.312 & 0.497 \\
Loss For Change & 207.312 & 203.400 & 207.312 & 0.497 \\
Exclusivity Unilinear & 213.312 & 208.633 & 213.312 & 6.497 \\
Alternative Relaxed Unilinear & 213.312 & 210.252 & 213.312 & 6.497 \\
Exclusivity Relaxed Unilinear & 214.197 & 203.457 & 227.413 & 7.382 \\
Alternative Rectilinear & 215.312 & 215.312 & 215.312 & 8.497 \\
Unstable Group & 219.312 & 219.312 & 219.312 & 12.497 \\
Full & 221.369 & 212.287 & 229.990 & 14.554 \\
Kin-Group & 221.471 & 213.944 & 231.072 & 14.656 \\
No Loss & 230.409 & 221.704 & 240.472 & 23.594 \\
Corporate & 233.003 & 217.748 & 248.653 & 26.188 \\
Rectilinear & 258.135 & 242.313 & 278.265 & 51.320 \\
Gain From None & & & &
\end{tabular}

615

616

617

618

619

620

621

622 
Table S6: Support for alternative models of land ownership, coded as binary (presencelabsence of any land ownership available to a majority of the society's population; absence of ownership for a majority of community members treated as reference level). $n=65$ societies.

627

628

629

630

631

632

633

634

635

\section{Model}

Neighbor Effect + Productivity Uncertainty

Neighbor Effect

Neighbor Effect + Distance to Coast

Neighbor Effect + Productivity Uncertainty + Reliance on Agriculture

Neighbor Effect + Reliance on Agriculture

Neighbor Effect + Productivity Uncertainty + Intensive Agriculture

Neighbor Effect + Productivity Uncertainty + Productivity

Neighbor Effect + Reliance on Agriculture + Intensive Agriculture

Neighbor Effect + Productivity Uncertainty + Mountains

Neighbor Effect + Intensive Agriculture

Neighbor Effect + Productivity Uncertainty + Distance to Coast

\begin{tabular}{lll} 
AICc & $\Delta$ AICc & AICw \\
\hline 58.41 & 0.00 & 0.09 \\
\hline 59.63 & 1.22 & 0.05 \\
\hline 59.82 & 1.42 & 0.05 \\
\hline 59.82 & 1.42 & 0.05 \\
\hline 59.89 & 1.49 & 0.04 \\
\hline 59.97 & 1.56 & 0.04 \\
\hline 60.12 & 1.71 & 0.04 \\
\hline 60.59 & 2.18 & 0.03 \\
\hline 60.59 & 2.19 & 0.03 \\
\hline 60.62 & 2.21 & 0.03 \\
\hline 60.64 & 2.24 & 0.03 \\
\hline
\end{tabular}

\section{Table S7: Multi-model average for models of land ownership in agricultural societies (full average)} excluding five societies that did not rely on agriculture for the majority of their subsistence (see Methods for details) $(n=60)$. Intensive agriculture coded as binary (presencelabsence of intensive agriculture; absence of intensive agriculture treated as reference level). Land ownership coded as binary (presence/absence of any land ownership available to a majority of the society's population; absence of ownership for most community members treated as reference level). Standardized coefficients are presented.

\begin{tabular}{lllll} 
Parameter & $\boldsymbol{\beta}$ coefficient & $\begin{array}{l}\text { Standard } \\
\text { error }\end{array}$ & z value & RVI \\
\hline (Intercept) & -2.963 & 1.427 & 2.034 & 1.00 \\
\hline Neighbor Effect & 8.150 & 2.322 & 3.433 & 1.00 \\
\hline Productivity & 0.064 & 0.175 & 0.360 & 0.36 \\
\hline Productivity Uncertainty & -0.064 & 0.218 & 0.290 & 0.34 \\
\hline Mountains & 0.007 & 0.115 & 0.117 & 0.29 \\
\hline Intensive Agriculture & -0.152 & 0.561 & 0.265 & 0.26 \\
\hline Distance to Coast & -0.002 & 0.236 & 0.007 & 0.23 \\
\hline Reliance on Agriculture & 0.010 & 0.493 & 0.019 & 0.23 \\
\hline
\end{tabular}

Marginal $\mathrm{R}_{\mathrm{GLMM}}^{2}=0.51$, and conditional $\mathrm{R}_{\mathrm{GLMM}}^{2}=0.60$

Table S8: Support for alternative models of land ownership, coded as binary (presencelabsence of any land ownership available to a majority of the society's population; absence of ownership for a majority of community members treated as reference level). Sample excludes five societies that did not rely on

641 agriculture for the majority of their subsistence (see Methods for details) $(n=60)$.

\begin{tabular}{llll} 
Model & AICc & DAICc & AICw \\
\hline Neighbor Effect & 52.22 & 0.00 & 0.12 \\
\hline Neighbor Effect + Productivity & 53.32 & 1.10 & 0.07 \\
\hline
\end{tabular}


Manuscript Preprint. Currently in revision following peer-review

\begin{tabular}{lccc}
\hline Neighbor Effect + Mountains & 53.40 & 1.18 & 0.07 \\
\hline Neighbor Effect + Productivity Uncertainty & 53.41 & 1.20 & 0.07 \\
\hline Neighbor Effect + Intensive Agriculture & 54.02 & 1.80 & 0.05 \\
\hline Neighbor Effect + Productivity Uncertainty + Productivity & 54.12 & 1.90 & 0.05 \\
\hline Neighbor Effect + Distance to Coast & 54.34 & 2.12 & 0.04 \\
\hline Neighbor Effect + Reliance on Agriculture & 54.52 & 2.30 & 0.04 \\
\hline Neighbor Effect + Mountains + Productivity & 55.29 & 3.07 & 0.03 \\
\hline Neighbor Effect + Intensive Agriculture + Productivity & 55.44 & 3.22 & 0.02 \\
\hline
\end{tabular}

642 